\title{
Therapeutic potential for cytokine antagonists: Thalidomide and pentoxifylline in Hansen's disease
}

\author{
THERESA C PETERSON PhD
}

\begin{abstract}
TC PETERSON. Therapeutic potential for cytokine antagonists: Thalidomide and pentoxifylline in Hansen's disease. Can J Infect Dis 1995;6(1):30-33. Cytokine antagonists are a group of drugs defined by their actions on specific cytokines. Cytokine antagonists can inhibit action of cytokines by acting directly on receptors, by affecting production of cytokines or by binding to cytokines and preventing their subsequent action. Recent evidence suggests that Hansen's disease, which is characterized by reactional states, is associated with elevated serum levels of tumour necrosis fac tor- $\alpha$ (TNF- $\alpha$ ) and interleukin- $1 \beta$ during these reactional states. Thalidomide, a drug used to treat reactional states in Hansen's disease, has been reported to enhance degradation of TNF- $\alpha$ mRNA. Pentoxifylline has also been reported to alter TNF- $\alpha$ mRNA levels by inhibiting TNF-a transcription. Combination of these two drugs as cytokine antagonists may prove to be beneficial as therapeutic agents in the treatment of reactional states in Hansen's disease. Pentoxifylline may prove to be beneficial in the treatment of reactional states in Hansen's disease patients who are female and of childbearing age. Cytokine antagonists alone or in combination will likely fill a niche in future therapeutics.
\end{abstract}

Key Words: Antagonists, Cytokine, Hansen's disease, Pentoxifylline, Thalidomide, Tumour necrosis factor- $\alpha$

\begin{abstract}
Potentiel thérapeutique des antagonistes des cytokines : thalidomide et pentoxifylline dans la maladie de Hansen

RÉSUMÉ : Les antagonistes des cytokines forment un groupe de médicaments qui se définissent par leurs actions spécifiques sur les cytokines. Ils peuvent inhiber ces dernières en agissant directement sur leurs récepteurs, en affectant leur production ou en se liant à elles pour ainsi les neutraliser. Selon des résultats récents, la maladie de Hansen, caractérisée par des états réactionnels, est associée à des taux sériques élevés de facteur- $\alpha$ de nécrose tumorale (TNF- $\alpha$ ) et d'interleukine-1 $\beta$ durant ces états réactionnels. La thalidomide, un médicament utilisé pour traiter de tels états dans la maladie de Hansen a été révélée apte à favoriser la dégradation du TNF- $\alpha$ mRNA. La pentoxifylline s'est également révélée capable de modifier les taux de TNF- $\alpha$ mRNA en inhibant la transcription du TNF- $\alpha$. L'association de ces deux médicaments comme antagonistes des cytokines peut se révéler avantageuse dans le traitement des états réactionnels propres à la maladie de Hansen. La pentoxifylline peut être un traitement bénéfique dans le traitement des états réactionnels propres à la maladie de Hansen chez les femmes en âge de procréer. Les antagonistes des cytokines, seuls ou en association, sont sans doute appeler à jouer un rôle thérapeutique.
\end{abstract}

Departments of Medicine and Pharmacology, Faculty of Medicine, Dalhousie University, Halifax, Nova Scotia

Correspondence and reprints: Dr TC Peterson, Clinical Research Centre, Room C103, Dalhousie University, Halifax, Nova Scotia B3H

4H7. Telephone (902) 494-2571, Fax (902) 494-1624

Received for publication December 21, 1993. Accepted May 13, 1994 
A CCORDING TO A RECENT REPORT, 5 MILLION PEOPLE SUFFER from Hansen's disease worldwide (1). Hansen's disease (leprosy) is characterized by two reactional states (2). Type I reactions of Hansen's disease involve mild erythema and edema while type II reactions involve erythematous lesions lasting from several days to weeks.

Type I reactions will respond to nonsteroidal anti- inflammatory drugs (NSAIDS). Severe type I reactions involving neuropathy or neuritis, ulceration and edema of the hands, face and feet is an indication for corticosteroid therapy (2). Initially high dose prednisone 40 to $120 \mathrm{mg}$ daily may be necessary, and chronic therapy is often required. In the type II reaction (erythema nodosum leprosum [ENL]), cell-mediated immunity is increased (3) and circulating levels of C3 breakdown product C3D are increased (4). The reduction in interleukin (IL)-2 production observed in Hansen's disease patients is reversed during ENL (5). ENL is subdivided into mild and severe grades for choice of therapeutics. In mild ENL NSAIDS provide symptomatic relief. In severe ENL, when neuritis, severe systemic reaction (high fever, etc), iridocyclitis or skin ulceration are present, corticosteroid or thalidomide treatment is used.

Thalidomide was originally used as a sedative in ENL and was found to improve symptoms of the reaction (6). For men and postmenopausal women, thalidomide is a drug of choice for ENL (7). The response to thalidomide therapy is rapid; within 24 to $48 \mathrm{~h}$ there is a decrease in fever and in numbers of lesions. ENL rapidly responds to thalidomide therapy, which may be better than long term steroid treatment (8).

On a cautionary note a recent report by Crawford (9) indicates that thalidomide itself can cause peripheral neuropathies, which can be severe and irreversible. Recently thalidomide has been reported to cause thalidomide neuropathy (10) when used in other treatment regimens (11). It is obvious that the current treatment regimens for reactional states in Hansen's disease carry with them the potential for severe side effects.

The mechanism of action of thalidomide in ENL is not known but recent reports suggest that thalidomide selectively inhibits tumour necrosis factor (TNF)- $\alpha$ production (12) by enhancing degradation of TNF- $\alpha$ mRNA (13). Corticosteroids have anti-inflammatory action and can inhibit translation of TNF- $\alpha$ mRNA, ie, they act post-transcriptionally (14); but long term steroid therapy carries with it the possibility of Cushingoid syndrome. Delaying treatment of the reactional states of Hansen's disease can result in irreversible nerve damage (15).

The role of cell-mediated immunity in lepromatous leprosy, particularly the importance of lymphokines and cytokines in Hansen's disease, is the subject of much research (16). Recent studies report elevated serum levels of TNF- $\alpha$ and IL-1 $\beta$ during leprosy reactional states (17). This is in contrast to an earlier report (18) but likely reflects differences in methods of measuring cytokines (radioimmunoassay) versus cytokine activity (bioassay). Modification of cytokine production eg, IL-1 and TNF- $\alpha$, can occur with currently used antilepromatous drugs, including corticosteroids (14) and thalidomide (12), and this may partially explain their mechanism of action in Hansen's disease.

Several recent reports suggest that pentoxifylline can inhibit the synthesis and action of TNF- $\alpha$ (19-21). Pentoxifylline reduces TNF- $\alpha$ MRNA by inhibiting TNF- $\alpha$ transcription, thus suppressing TNF- $\alpha$ gene expression (22). These actions are distinct from the actions of thalidomide or corticosteroids on TNF- $\alpha$ synthesis, suggesting the possibility of synergism when these drugs are used in combination. Pentoxifylline has also been reported to inhibit IL-1-mediated functions $(23,24)$. Inhibition of phosphodiesterase by pentoxifylline would elevate CAMP (25) and thereby reduce transcription of TNF- $\alpha$ (26). Due to its effects on TNF- $\alpha$ and IL-1, pentoxifylline may be an effective therapeutic agent in the treatment of reactional states in Hansen's disease alone or when used in combination with thalidomide.

In addition to its effects on TNF- $\alpha$ and IL-1, pentoxifylline inhibits neutrophil function $(27,28)$. Neutrophils play an important role in ENL (29), so this effect of pentoxifylline may prove to be an added benefit in Hansen's disease, particularly ENL.

Pentoxifylline appears to be a very safe drug when used in chronic treatment of other disorders (30). Chronic use of pentoxifylline for up to one year carries a low instance of side effects, which include gastrointestinal disturbances in $2.6 \%$ of patients treated, while fewer than $0.25 \%$ of patients treated experience cardiovascular, psychological, neurological, hepatic or dermatological effects (31).

In reactional states of Hansen's disease, pentoxifylline may prove to be an effective therapeutic agent, with particular indication in women of childbearing age where thalidomide use is contraindicated. In the subgroup of Hansen's disease patients in whom thalidomide is currently used, the combination of thalidomide with pentoxifylline will likely provide additional therapeutic benefit. Both drugs affect TNF- $\alpha$ transcription, but at different sites, thus providing the possibility of synergistic activity. It is understood, however, that a certain level of cytokine production (eg, TNF- $\alpha$ ) can be beneficial (32), so careful titration of cytokine inhibition will likely be necessary to achieve optimum results.

The role of cytokine antagonism by pentoxifylline in the treatment of other cytokine-mediated diseases, disorders and injury is becoming increasingly evident in the literature. Pentoxifylline has been shown to prolong survival in animal models of peritonitis (33) and bacteremia (34), potentially through a mechanism whereby pentoxifylline inhibits TNF- $\alpha$-induced polymorphonuclear leukocyte activation including polymorphonuclear leukocyte adherence, degranulation and superoxide production (35). Pentoxifylline improves the hemodynamic and histological changes, as well as a decrease in neutrophil adhesiveness, in a pig fecal peritonitis model (36).

Reports in the literature suggest that pentoxifylline also reduces both septic- and TNF- $\alpha$-induced acute lung injury and multiple organ damage in the guinea pig (37-39). They also suggest that pentoxifylline attenuates edema formation in proteolytic enzyme-induced lung injury (40).

Hoffman and co-workers (41) report that pentoxifylline attenuates Escherichia coli-induced acute lung injury in guinea 
pigs. Further reports by Gibson et al (42) indicated that group $B$ streptococcus induces TNF- $\alpha$ in neonatal piglets and that pentoxifylline treatment both attenuates group $B$ streptococcus-induced TNF- $\alpha$ production and provides some improvement in pulmonary hemodynamics and hypoxemia in the piglet model. Noel et al (43) report that pentoxifylline inhibited lipopolysaccharide-induced serum TNF- $\alpha$ and protected the animals from the lethal effects of an intravenous challenge with lipopolysaccharide.

TNF has been implicated in the pathogenesis of sepsis, cancer cachexia (44), the cachexia of chronic heart failure (45), IL-2 toxicity $(46)$, ischemia/reperfusion injury $(47,48)$, cerebral malaria (49), pulmonary fibrosis (50) and acid aspirationinduced lung injury (51). The blockade of TNF- $\alpha$ action with neutralizing anti-TNF antibodies has improved some of these conditions, including septic shock and IL-2 toxicity. This suggests that there may be an important role for cytokine antagonists in these and other conditions in which TNF appears to have

1. Mahon AC, Nurlign A, Kebede B, Becx-Bleumink M, Lefford MJ. Urinary phenolic glycolipid 1 in the diagnosis and management of leprosy. J Infect Dis 1991;163:653-6.

2. Goodless DR, Ramos-Caro FA, Flowers FP. Reactional states in Hansen's disease: practical aspects of emergency management. South Med J 1991;84:237-8.

3. Rao TD, Rao R. Enhanced cell-mediated immune responses in erythema nodosum reactions of leprosy. Int J Lepr 1987;55:36-41.

4. Bjorvatn B, Barnetson RS, Kronvall G. Immune complexes and complement hypercatabolism in patients with leprosy. Clin Exp Immunol 1976;26:388-96.

5. Modlin RL, Mehra V, Jordan R, et al. In situ and in vitro characterization of the cellular immune response in erythema nodosum leprosum. J Immunol 1986;136:883-6.

6. Sheskin J. Thalidomide in treatment of lepra reactions. Clin Pharmacol Ther 1965;6:303-6.

7. Sheskin J. The treatment of lepra reaction in lepromatous leprosy. Int J Dermatol 1980;19:318-22.

8. Malin RS, Waters MFR, Shehade SA, Roberts MM. Leprosy in reaction: a medical emergency. BMJ 1991;302:1324-6.

9. Crawford CL. Use of thalidomide in leprosy. BMJ 1991;302:1603-4.

10. Knop J, Bonsmann G, Happle R, et al. Thalidomide in the treatment of 60 cases of chronic discoid lupus erythematosus. Br J Dermatol 1983;108:461-6.

11. Wulf $\mathrm{CH}$, Hoyer $\mathrm{H}$, Asboe-Hansen $\mathrm{G}$, Brodthagen $\mathrm{H}$. Development of polyneuropathy during thalidomide therapy. $\mathrm{Br} \mathrm{J}$ Dermatol 1985;112:475-80.

12. Sampaio EP, Sarno EN, Galilly R, Cohn ZA, Kaplan G. Thalidomide selectively inhibits tumor necrosis factor a production by stimulated human monocytes. J Exp Med 1991;173:699-703.

13. Moreira AL, Sampaio EP, Zmuidzinas A, Frindt $P$, Smith KA, Kalplan $\mathrm{G}$. Thalidomide exerts its inhibitory action on tumor necrosis factor alpha by enhancing mRNA degradation. $\mathrm{J}$ Exp Med 1993;177:1675-80.

14. Wong GHW, Goeddel DV. Biological activities and production of TNF $\alpha$. In: Powanda M, Oppenhein J, Kluger MJ, Dinarello C, eds. Monokines and Other Nonlymphocytic Cytokines. New York: Alan R Liss Inc, 1988:251-60.

15. Waters MFR. Leprosy (Hansen's disease/hanseniasis). In: Weatherall DJ, Ledingham JGG, Warrell DA, eds. Oxford Textbook of Medicine, 2nd edn. Oxford: Oxford University Press, 1987:5.305-13. a deleterious effect. It has clearly been shown that pentoxifylline blocks TNF- $\alpha$ at the MRNA level (52) and can be used successfully in vivo for the treatment of diseases with high endogenous TNF- $\alpha$ levels $(39,43,53-56)$.

The release and/or action of other cytokines has recently been reported to be inhibited by pentoxifylline treatment (57$60)$, thus providing further roles for pentoxifylline as a cytokine antagonist in diseases and disorders involving other cytokines $(61,62)$.

The future application of pentoxifylline and thalidomide, alone or in combination, as well as other cytokine inhibitors has wide implications in therapeutics.

ACKNOWLEDGEMENTS: I extend thanks to Dr Bill Levis for valuable discussion and to Sue Moore for typing the manuscript.

16. Kaplan G, Cohn ZA. Leprosy and cell-mediated Immunity. Curr Opin Immunol 1991;3:91-6.

17. Sarno EN, Grau GE, Vieira LM, Nery JA. Serum levels of tumor necrosis factor $\alpha$ and IL-1 $\beta$ during leprosy reactional states. Clin Exp Immunol 1991;84:103-8.

18. Silva CL, Foss NT. Tumor necrosis factor in leprosy patients. J Infect Dis 1989;159:787.

19. Strieter RM, Remick DG, Ward PA, et al. Cellular and molecular regulation of TNF by pentoxifylline. Biochem Biophys Res Commun 1988;155:1230-6.

20. McHutchison JG, Runyon BA, Dragnesku JO, Cominelli F, Person J, Castracane J. Pentoxifylline may prevent renal impairment in severe acute alcoholic hepatitis. Hepatology 1991;14:96A.

21. Currin RT, Lichtman SN, Thurman RG, Lemasters JJ. Pentoxifylline adenosine prostaglandin $\mathrm{E}$ and nisoldipine inhibit TNF release from LPS stimulated rat Kupffer cells. Hepatology 1991;14:165A.

22. Doherty G, Jensen J, Alexander HR, Buresh CM, Norton JA. Pentoxifylline suppression of tumor necrosis factor gene transcription. Surgery 1991;110:192-8.

23. Berman B, Duncan M. Pentoxifylline inhibits normal human dermal fibroblast in vitro proliferation, collagen, glycose aminoglycan and fibronectin production and increases collagenase activity. J Invest Dermatol 1989;92:605-10.

24. Sullivan GW, Carper HT, Novick WJ, Mandell GL. Inhibition of the inflammatory action of IL-1 and TNF on neutrophil function by pentoxifylline. Infect Immun 1988;56;1722-9.

25. Taffett $\mathrm{S}$. Regulation of TNF $\alpha$ gene expression by lipopolysaccharide cAMP and interferon. In: Powanda MC, Oppenheim JJ, Kluger MJ, Dinarello CA, eds. Monokines and Other Nonlymphocytic Cytokines. New York: Alan R Liss, Inc, 1988:67-72.

26. Semmler J, Sinha B, Stoll D, Fulle HJ, Schonharting MM, Entres $\mathrm{S}$. Xanthine derivatives: comparison of the potency to suppress TNF $\alpha$ synthesis with the extent of cAMP-elevation. Cytokine 1991;3:457.

27. Mandell GL. ARDS neutrophils and pentoxifylline. Am Rev Respir Dis 1988;138:1103.

28. Larsen C, Zachariae C, Mukaida N, et al. Proinflammatory cytokines interleukin 1 and tumor necrosis factor induce cytokines that are chemotactic for neutrophils T cells and monocytes. In: Melli M, Parente L, eds Cytokines and Lipocortins in Inflammation and Differentiation. New York: Wiley-Liss Inc, 1990:419-31.

29. Goihman-Yahr M, Rodrigues-Ochoa G, Aranzazu N, et al. In 
vitro activation of neutrophils by suspensions of Mycobacterium leprae. Int J Lepr Other Mycobact Dis 1979;47:570-4.

30. Ward A, Clissold SP. Pentoxifylline: a review of its pharmacodynamic and pharmacokinetic properties and therapeutic efficacy. Drugs 1987;34:50-97.

31. Sternitzky R, Seige K. Clinical investigation of the effects of pentoxifylline in patients with severe peripheral occlusive vascular disease. Curr Med Res Opin 1985;9:602-10.

32. Havell EA. Evidence that tumor necrosis factor has an important role in antibacterial resistance. J Immunol 1989;143:2894.

33. Chalkiadakis GE, Kostakis A, Karayannacos PE, et al. Pentoxifylline in the treatment of experimental peritonitis in rats. Arch Surg 1985;120:1141-4.

34. Sullivan GW, Patselas TN, Redick JA, Mandell GL. Enhancement of chemotaxis and protection of mice from infection. Trans Assoc Am Physicians 1984;97:337-45.

35. Sullivan GW, Carper HT, Novick WJ Jr, Mandell GL. Inhibition of the inflammatory action of interleukin-1 and tumor necrosis factor (alpha) on neutrophil function by pentoxifylline. Infect Immun 1988;56:1722-9.

36. Tighe D, Moss R, Hynd J, et al. Pretreatment with pentoxifylline improves the hemodynamic and histologic changes and decreases neutrophil adhesiveness in a pig fecal peritonitis model. Crit Care Med 1990;18:184-9.

37. Ishizaka A, Wu Z, Stephens KE, et al. Attenuation of acute lung injury in septic guinea pigs by pentoxifylline. Am Rev Respir Dis 1988;138:376-82.

38. Lilly CM, Sandhu JS, Ishzaka A, et al. Pentoxifylline prevents tumor necrosis factor-induced lung injury. Am Rev Respir Dis 1989;139:1361-8.

39. Harada $\mathrm{H}$, Ishizaka $\mathrm{A}$, Yonemaru $\mathrm{M}$, et al. The effects of aminophylline and pentoxifylline on multiple organ damage after Escherichia coli sepsis. Am Rev Respir Dis 1989;140:974.

40. Rosenfeld BA, Toung TJ, Sendak MJ, Breslow MJ, Hutchins GM, Traystman RJ. Pentoxifylline attenuates edema formation in proteolytic enzyme-induced lung injury. Crit Care Med 1990;18:1394-7.

41. Hoffmann H, Hatherill JR, Crowley J, et al. Early post-treatment with pentoxifylline or dibutyryl cAMP attenuates Escherichia coli-induced acute lung injury in guinea pigs. Am Rev Respir Dis 1991;143:289-93.

42. Gibson RL, Redding GJ, Henderson WR, Truog WE. Group B streptococcus induces tumor necrosis factor in neonatal piglets. Am Rev Respir Dis 1991;143:598-604.

43. Noel $P$, Nelson $S$, Bokulic R, et al. Pentoxifylline inhibits lipopolysaccharide-induced serum tumor necrosis factor and mortality. Life Sci 1990;47:1023-9.

44. Oliff $A$, Defeo-Jones $D$, Boyer $M$, et al. Tumors secreting the human TNF/cachetin induce cachexia in mice. Cell 1987;50:555-63.

45. Levine B, Kalman J, Mayer L, Fillit HM, Packer M. Elevated circulating levels of tumor necrosis factor in severe chronic heart failure. N Engl J Med 1990;323:236-41.

46. Fraker DL, Langstein HN, Norton JA. Passive immunization against tumor necrosis factor partially abrogates interleukin 2 toxicity. J Exp Med 1989;170:1015-20.

47. Caty MG, Guice KS, Oldham KT, Remick DG, Kunkel SI. Evidence for tumor necrosis factor-induced pulmonary microvascular injury after intestinal ischemia-reperfusion injury. Ann Surg 1990;212:694-700.

48. Colletti LM, Remick DG, Burtch GD, Kunkel L, Strieter RM, Campbell DA. Role of tumor necrosis factor-a in the pathophysiologic alterations after hepatic ischemia/reperfusion injury in the rat. J Clin Invest 1990;85:193-7.

49. Kwiatkowski D, Hill AVS, Sambou I, et al. TNF concentration in fatal cerebral, non-fatal cerebral, and uncomplicated Plasmodium falciparum malaria. Lancet 1990;336:1201-4.

50. Piguet PF, Collart MA, Grau GE, Sappine AP, Vassalli P. Requirement of tumor necrosis factor for development of silica-induced pulmonary fibrosis. Nature 1990;344:245-7.

51. Goldman G, Welbourn R, Kobzik L, Valeri CR, Shepro D, Hechtman HB. Tumor necrosis factor- $\alpha$ mediates acid aspiration-induced systemic organ injury. Ann Surg 1990;212:513-20.

52. Han J, Thompson P, Beutler B. Dexamethosone and pentoxifylline inhibit endotoxin-induced cachectin/tumor necrosis factor synthesis at separate points in the signaling pathway. $J$ Exp Med 1990;172:391.

53. Zabel P, Schonharting MM, Wolter DT, Schade UF. Oxpentifylline in endotoxawmia. Lancet 1989;50:1474.

54. Dezube JB, Fridovich-Keil JL, Bouvard I, Lange RF, Pardee AB. Pentoxifylline and well being in patients with cancer. Lancet 1990;335:662.

55. Bianco JA, Almgren J, Kern DL, et al. Evidence that oral pentoxifylline reverses acute renal dysfunction in bone marrow transplant recipients receiving amphotericin B and cyclosporine. Transplantation 1991;51:925.

56. Bianco JA, Appelbaum FR, Nemunaitis J, et al. Phase I-II trial of pentoxifylline for the prevention of transplant-related toxicities following bone marrow transplantation. Blood 1991;78:1205.

57. Singer JW, Bianco JA, Takahashi G. Pentoxifylline (PTX) 1-(5-oxohexyl)-3,7-dimethylxanthine inhibits human T-cell activation and proliferation in vitro. Clin Res 1991;39:463a.

58. Singer JW, Bianco JA, Takashashi G, Andrews F. Pentoxifylline (PTX) inhibits human T-cell activation without blocking IL-2 upregulation. Proc Int Soc Exp Hematol 1991:343.

59. Tilg H, Eibl B, Pichl M. Immune response modulation by pentoxifylline in vitro. Transplantation 1993;56:196-201.

60. Peterson TC, Isbrucker RA. Inhibition of PDGF-driven fibroproliferation. Cytokine 1991;3:502.

61. Peterson TC. Pentoxifylline prevents fibrosis in an animal model and inhibits platelet derived growth factor driven proliferation of fibroblasts. Hepatology 1993;17:486-93.

62. Berman B, Duncan MR. Pentoxifylline inhibits the proliferation of human fibroblasts derived from keloid, scleroderma and morphoea skin and their production of collagen, glycosaminoglycans and fibronectin. $\mathrm{Br} \mathrm{J}$ Dermatol 1990;123:339-46. 


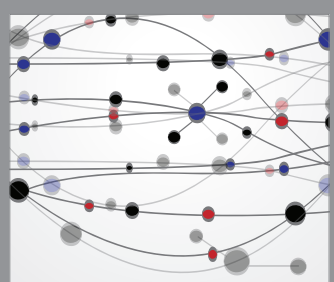

The Scientific World Journal
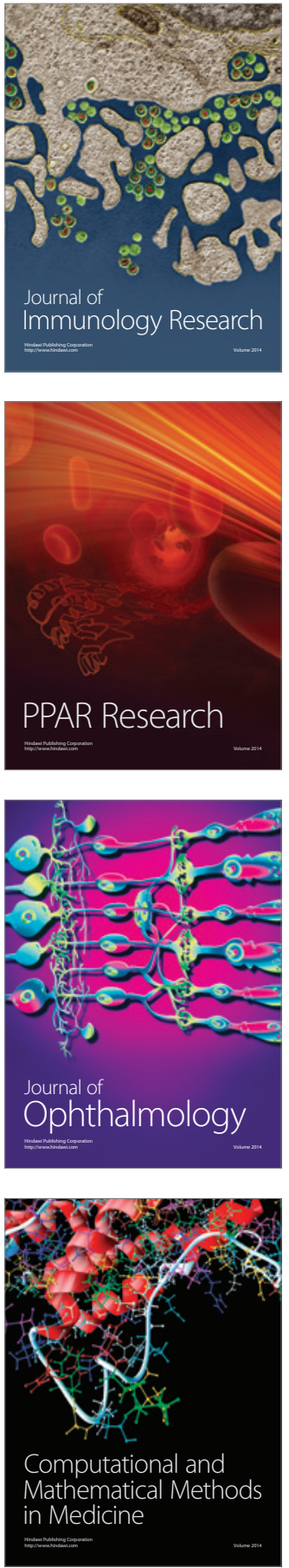

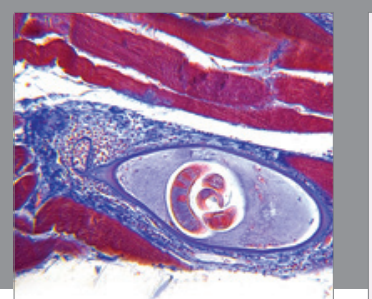

Gastroenterology Research and Practice

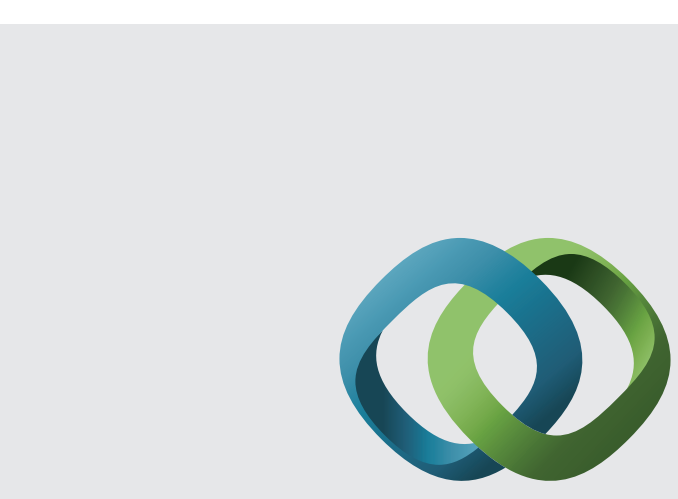

\section{Hindawi}

Submit your manuscripts at

http://www.hindawi.com
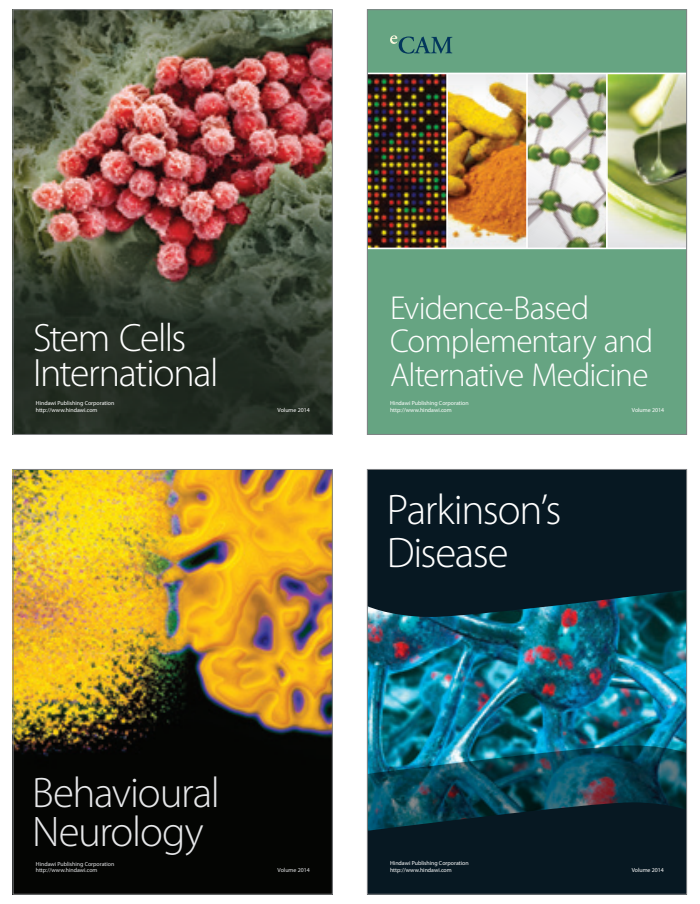
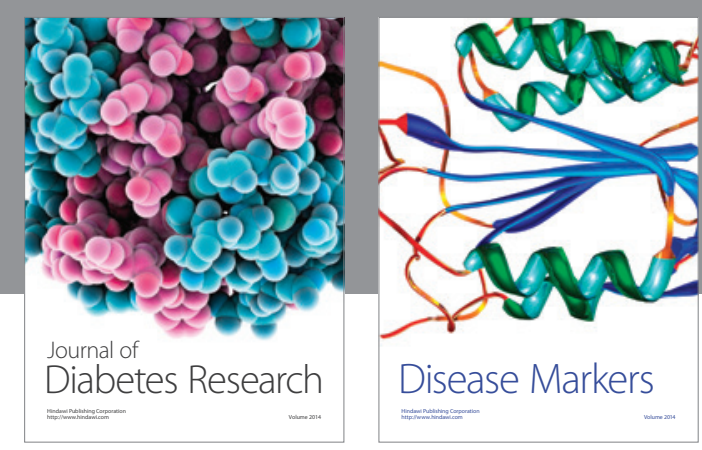

Disease Markers
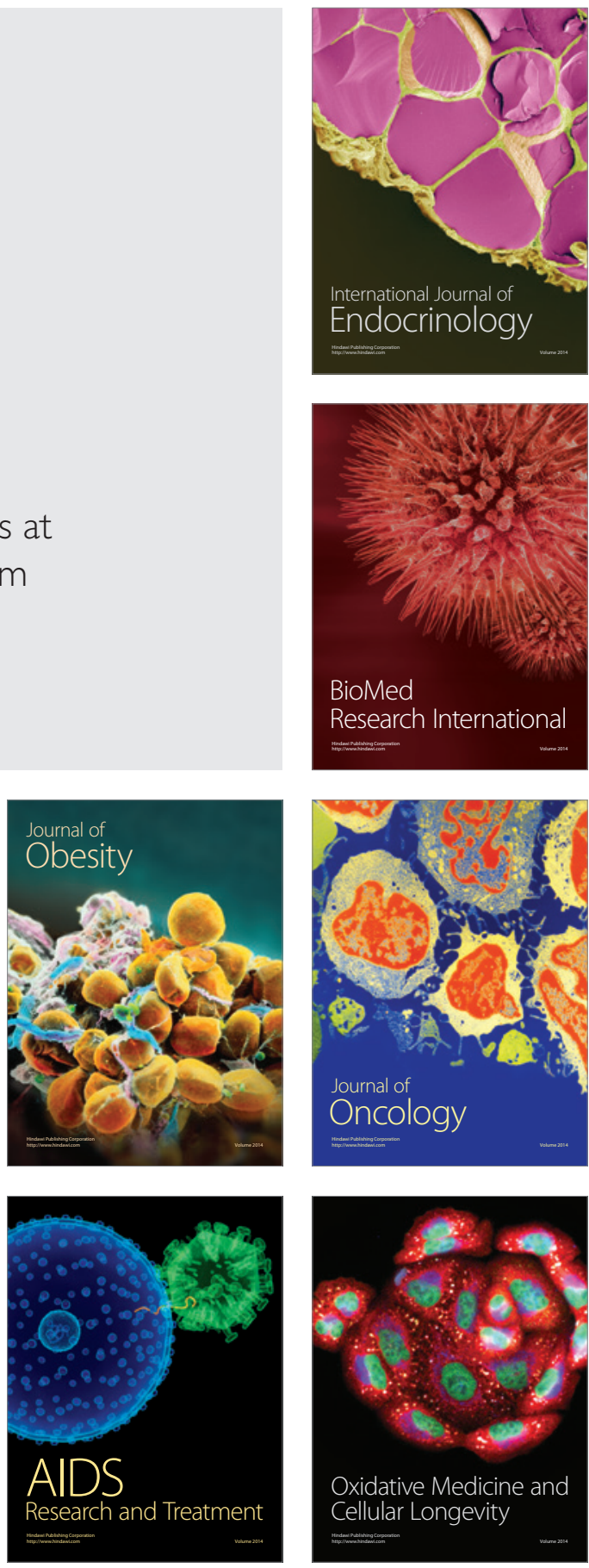